\title{
Production of tripropeptins in media supplemented with precursors based on the biosynthetic pathway
}

\author{
Hideki Hashizume, ${ }^{a}$ Chisato Nosaka, ${ }^{a}$ Sehei Hirosawa, ${ }^{b}$ Masayuki Igarashi ${ }^{a}$, \\ Yoshio Nishimura, ${ }^{a}$ and Yuzuru Akamatsu ${ }^{a}$ \\ ${ }^{a}$ Microbial Chemistry Research Center, 3-14-23 Kamiosaki, Shinagawa-ku, Tokyo 141-0021, \\ Japan \\ ${ }^{b}$ Hiyoshi Medicinal Chemistry Institute, Microbial Chemistry Research Center 3-14-17 Ida, \\ Nakahara-ku, Kawasaki-shi, Kanagawa 211-0035, Japan \\ E-mail: hashizumeh@bikaken.or.jp
}

Dedicated to Professor Atta-ur-Rahman on his 65th birthday

\begin{abstract}
Tripropeptins (TPPs), the non-ribosomal cyclic depsipeptide antibiotics, are isolated from the culture broth of Lysobacter sp., and exhibit potent antimicrobial activity against gram-positive bacteria. TPPs consist of a common peptide ring composed of eight amino acids and a branched chain fatty acid from $\mathrm{C}-12$ to $\mathrm{C}-17$. Based on the biosynthetic pathway of branched chain fatty acids, the effects of supplement of their postulated biosynthetic precursors on production ratio of TPPs were examined. As expected, the corresponding TPP-components were predominantly produced by addition of leucine, isovaleric acid, 3-methyl-2-oxo-butanoic acid, 4-methyl-2-oxopentanoic acid and 3-hydroxy-14-methylpentadecanoic acids, but not by addition of valine.
\end{abstract}

Keywords: Biosynthesis, branched chain fatty acid, cyclic lipopeptide, tripropeptins

\section{Introduction}

Recently, we have isolated novel lipopeptide antibiotics designated tripropeptin (TPP) A, B, C, D, E and Z from culture broth of Lysobacter sp. BMK333-48F3. ${ }^{1,2}$ TPPs are cyclic depsipeptides consisting of a common peptide ring composed of eight amino acids and a branched chain fatty acid from $\mathrm{C}-12$ to $\mathrm{C}-17$ as shown in Figure 1.,3 


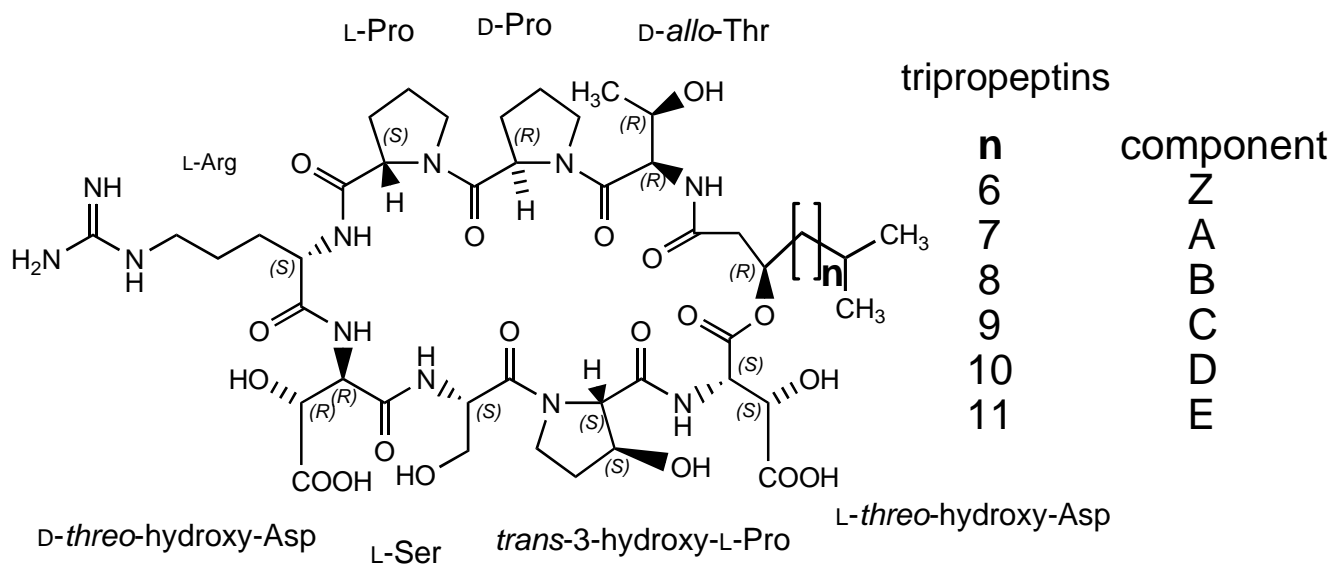

Figure 1. Structure of TPPs.

They show potent antimicrobial activities against gram-positive bacteria including methicillin-resistant Staphylococcus aureus (MRSA), vancomycin-resistant Enterococcus spp. and penicillin-resistant Streptococcus pneumoniae. Their antimicrobial activities are well proportioned to the length of fatty acyl chain up to C-16 (Table 1$){ }^{2}$

Table 1. Antimicrobial activities of TPPs and related compounds against MSSA and MRSA

\begin{tabular}{lllllll}
\hline test sample & \multicolumn{3}{c}{ MIC $(\mu \mathrm{g} / \mathrm{ml})$} & \multicolumn{3}{c}{ MIC $(\mu \mathrm{g} / \mathrm{ml})$} \\
& \multicolumn{3}{c}{ MSSA (10 strains) } & \multicolumn{3}{c}{ MRSA (10 strains) } \\
& range & MIC $_{50}$ & MIC $_{90}$ & range & MIC $_{50}$ & MIC $_{90}$ \\
\hline tripropeptin A(C-13) & $3.13-12.5$ & 6.25 & 6.25 & $0.78-12.5$ & 6.25 & 12.5 \\
tripropeptin B (C-14) & $0.78-3.13$ & 1.56 & 3.13 & $0.39-3.13$ & 3.13 & 3.13 \\
tripropeptin C (C-15) & $0.39-0.78$ & 0.78 & 0.78 & 0.78 & 0.78 & 1.56 \\
tripropeptin D (C-16 & $0.39-0.78$ & 0.78 & 0.78 & 0.78 & 0.78 & 0.78 \\
tripropeptin E (C-17) & $0.39-0.78$ & 0.78 & 0.78 & 0.78 & 0.78 & 1.56 \\
tripropeptin Z (C-12) & $12.5-50$ & 50 & 50 & 50 & 50 & 100 \\
vancomycin & 0.78 & 0.78 & 0.78 & $0.39-1.56$ & 1.56 & 1.56 \\
teicoplanin & $0.39-0.78$ & 0.39 & 0.78 & $0.20-1.56$ & 0.78 & 1.56 \\
meropenem & $0.05-0.10$ & 0.10 & 0.10 & $6.25-50$ & 12.5 & 50 \\
levofloxacin & $0.05-0.39$ & 0.10 & 0.20 & $3.13-100$ & 25 & $>100$ \\
ofloxacin & $0.20-0.78$ & 0.39 & 0.39 & $6.25-100$ & 100 & $>100$ \\
ampicillin & $0.10-3.13$ & 0.78 & 3.13 & $6.25-50$ & 25 & 50 \\
arbekacin & $0.20-0.78$ & 0.39 & 0.78 & $0.20-0.39$ & 0.39 & 0.39 \\
erythromycin & $0.10-100$ & 0.20 & 12.5 & $>100$ & $>100$ & $>100$ \\
tetracycline & 0.20 & 0.20 & 0.20 & $1.56-50$ & 50 & 50 \\
fosfomycin & $3.13-50$ & 6.25 & 25 & $>100$ & $>100$ & $>100$ \\
\hline
\end{tabular}

Mueller Hinton agar (Difco) $37^{\circ} \mathrm{C}, 18 \mathrm{~h}$ 
The most effective component, tripropeptin D (TPPD) and the major component tripropeptin $\mathrm{C}$ (TPPC) are qualified as new drug candidates. However, as culture broth contains a lot of similar products, it is difficult to separate each analogs. Therefore, selective and effective production of the specific TPP component is required for industrial application.

In order to improve the productivity of specified TPPs, we have focused on the biosynthesis of branched chain fatty acids, since the chain length is the sole structural difference between the TPPs. Fortunately, the biosynthesis of branched chain fatty acids has already been elucidated in detail, $^{4}$ and the following coenzyme esters are known to be the primers involved in their biosynthesis. Coenzyme A esters of isovaleric acid, isobutyric acid and 2-methylbutyric acid could contribute to the productions of iso-fatty acid with odd number of carbon atoms, iso-fatty acids with even number of carbon atoms, and anteiso-fatty acids, respectively. These branched fatty acids can also be biosynthesized from the branched chain amino acids, namely leucine, valine and isoleucine, respectively, as shown in Figure 2. The improved productions of other cyclic lipopeptide antibiotics with acyl side chains have previously been achieved by supplement of these amino acids or fatty acids. $5,6,7$

Here, we report an improvement in the production ratio of TPPs by addition of the postulated precursors such as branched chain amino acids, short-chain carboxylic acids or 3-hydroxy fatty acids.
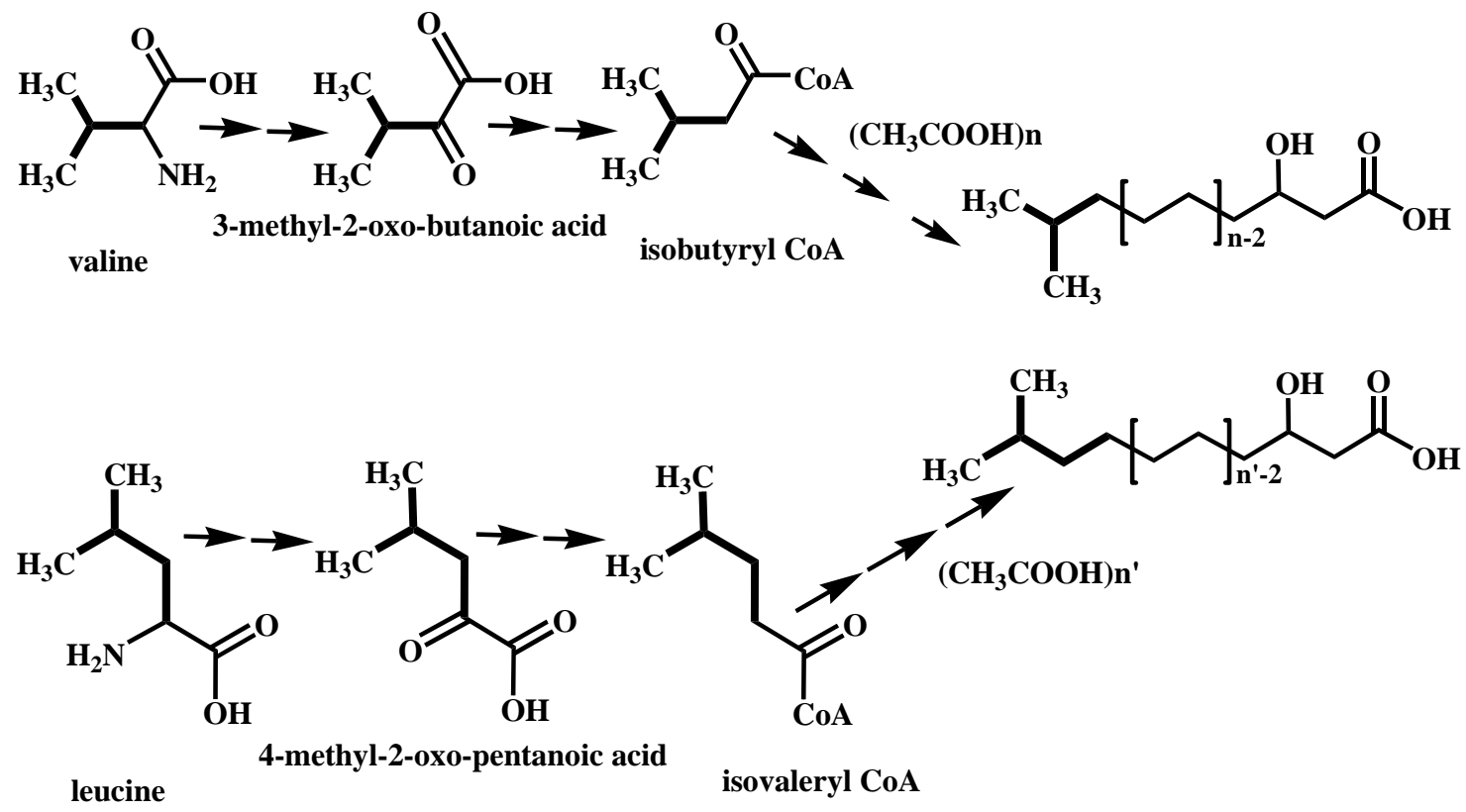

Figure 2. Branched-chain fatty acid synthetic pathway. 


\section{Results and Discussion}

Under the standard culture conditions, TPPs were produced in the ratio of TPPA (8.4\%), TPPB (8.9\%), TPPC (71.3\%) and TPPD (11.4\%). With the addition of L-leucine, a well-known precursor of branched-chain fatty acids to the culture medium, the production ratio of TPPC was increased in a dose-dependent manner, resulting in the predominant production of TPPC and diminished formation of TPPB and TPPD, as shown in Table 2 and Figure 3. A similar result was also observed by the addition of D-leucine, as shown in Table 2. A maximum ratio of TPPC (92\%) was achieved by adding $1.25-10 \mathrm{mg} / \mathrm{ml} \mathrm{L}$-leucine. Under the addition of L-leucine, neither growth inhibition nor enhancement of total amount of TPPs productivity was observed.

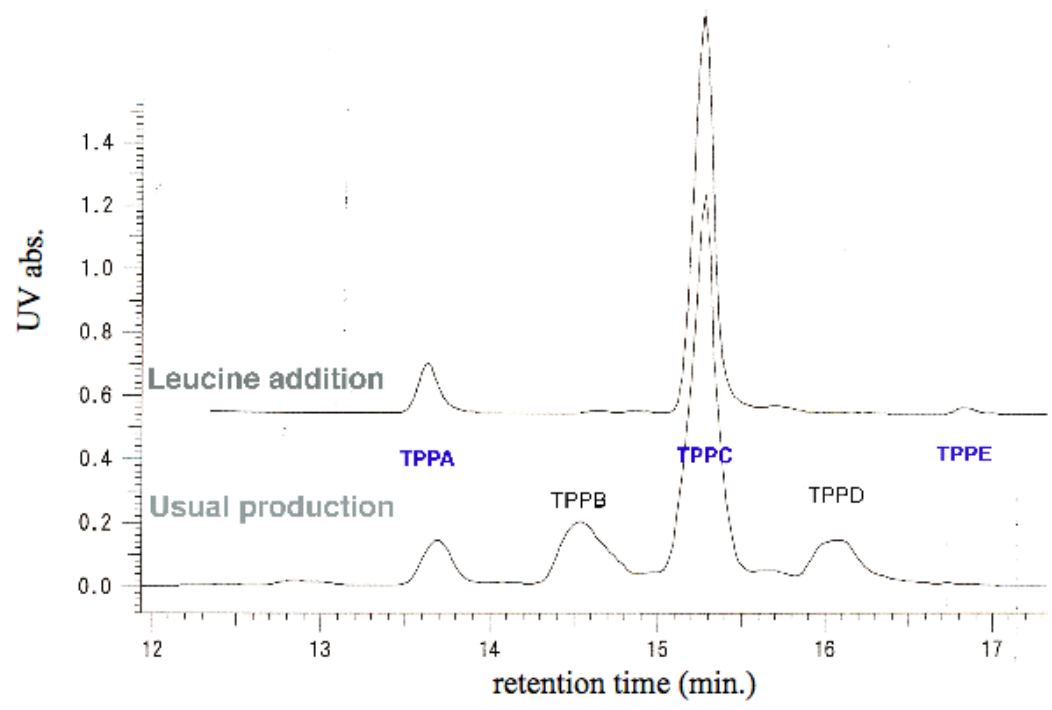

Figure 3. HPLC chromatograms (UV detection at $205 \mathrm{~nm}$ ) of TPPs production of standard culture (lower) and $1 \mathrm{~g}$ /flask of L-leucine was added to the culture (upper) (for chromatographic protocol see experimental section).

On the other hand, the addition of L- or D-valine to the culture medium did not significantly affect TPP production, as shown in Table 2. At high concentrations of L-valine and especially Dvaline, the productivity of TPPs was decreased, resulting in growth inhibition. 
Table 2. Effect of leucine and valine on TPPs production ratio

\begin{tabular}{|c|c|c|c|c|c|c|c|}
\hline \multirow{2}{*}{$\begin{array}{c}\text { Amino } \\
\text { acid }\end{array}$} & \multirow{2}{*}{$\begin{array}{c}\text { Dose } \\
(\mathrm{mg} / \mathrm{ml})\end{array}$} & \multirow{2}{*}{$\begin{array}{l}\text { Inhibition diameter } \\
\text { against } S \text {. aureus } \\
\text { Smith }(\mathrm{mm})\end{array}$} & \multirow[t]{2}{*}{$\mathrm{pH}$} & \multicolumn{4}{|c|}{ Ratio of TPPs $(\%)^{\mathrm{a}}$} \\
\hline & & & & A & B & $\mathrm{C}$ & $\mathrm{D}$ \\
\hline control & 0 & $23.5-24.5$ & 8.8 & 8.4 & 8.9 & 71.3 & 11.4 \\
\hline \multirow[t]{4}{*}{ L-leucine } & 0.31 & 24.5 & 8.8 & 3.9 & 4.2 & 87.1 & 4.8 \\
\hline & 0.63 & $23.5-24.0$ & 8.8 & 4.4 & 2.3 & 90.8 & 2.5 \\
\hline & 1.25 & $23.5-24.5$ & 8.6 & 7.6 & 0.3 & 92.1 & 0 \\
\hline & 10 & $23.0-24.0$ & 8.6 & 7.6 & 0.2 & 92.1 & 0.1 \\
\hline \multirow[t]{2}{*}{ D-leucine } & 0.31 & $24.0-24.5$ & 8.8 & 7.5 & 8.5 & 75.7 & 8.3 \\
\hline & 1.25 & $23.5-24.5$ & 8.6 & 11.4 & 2.8 & 85.1 & 0.7 \\
\hline \multirow[t]{2}{*}{ L-valine } & 1.25 & $23.5-24.0$ & 8.8 & 7.8 & 9.6 & 70.8 & 11.8 \\
\hline & 10 & $19.5-20.5$ & 8.4 & 6.3 & 8.9 & 72.1 & 12.7 \\
\hline \multirow[t]{2}{*}{ D-valine } & 1 & $20.5-21.0$ & 8.8 & 8.2 & 8.8 & 72.6 & 10.4 \\
\hline & 5 & 0 & 7.6 & N.D. & N.D. & N.D. & N.D. \\
\hline
\end{tabular}

${ }^{\text {a }}$ Percentage values are calculated by the peak area of HPLC analysis; N.D. not detected

Next, we examined effect of the addition of postulated precursors such as 3-methyl-2-oxobutanoic acid, 4-methyl-2-oxo-pentanoic acid and isovaleric acid on TPP production (Figure 2).

By adding 4-methyl-2-oxo-pentanoid acid or isovaleric acid, the productions of TPPC increased, and the addition of 3-methyl-2-oxo-butanoic acid increased TPPB and TPPD production in a dose-dependent manner. By addition of 3.3-10 mg/ml 3-methyl-2-oxo-butanoic acid increased TPPD formation by twofold (Table 3). These results were well-explained from the biosynthetic pathway shown in Figure 2. When the postulated precursors, such as 3-methyl-2oxo-butanoic acid, 4-methyl-2-oxo-pentanoic acid or isovaleric acid were added at the early beginning of cultivation ( 0 to $4 \mathrm{~h}$ after), severe growth inhibition of TPP-producing organisms was observed, and TPPs were not produced. Our studies have revealed that the addition of precursors such as 3-methyl-2-oxo-butanoic acid, 4-methyl-2-oxo-pentanoic acid and isovaleric acid to the culture at $8 \mathrm{~h}$ after cultivation is the optimum condition for TPP production.

These results indicate that the transaminases of the producing organisms act specifically on leucine, but not on valine, to produce $\alpha$-keto acids. This also suggests that 3 -methyl-2-oxobutanoic acid, a precursor of iso type, even carbon fatty acids could be derived from amino acids other than valine by an alternative metabolic pathway. 
Table 3. Effect of branched keto-acids and isovaleric acid on TPPs production

\begin{tabular}{|c|c|c|c|c|c|c|c|}
\hline \multirow[t]{2}{*}{ precursors } & \multirow{2}{*}{$\begin{array}{c}\text { Dose } \\
(\mathrm{mg} / \mathrm{ml})\end{array}$} & \multirow{2}{*}{$\begin{array}{l}\text { Inhibition } \\
\text { diameter against } \\
\text { S. aureus Smith } \\
\text { (mm) }\end{array}$} & \multirow[t]{2}{*}{ ph } & \multicolumn{4}{|c|}{ Ratio of TPPs $(\%)^{\mathrm{a}}$} \\
\hline & & & & A & $\mathrm{B}$ & $\mathrm{C}$ & $\mathrm{D}$ \\
\hline control & 0 & $24.5-25.5$ & $9.0-9.2$ & 7.8 & 11.5 & 68.3 & 12.4 \\
\hline 3-Me-2-O- & 0.4 & 24.5 & $9.0-9.2$ & 8.8 & 11.8 & 63.3 & 16.1 \\
\hline \multirow[t]{3}{*}{ butanoic acid* } & 1.1 & $25.0-26.0$ & 9.0 & 8.5 & 14.6 & 54.6 & 22.3 \\
\hline & 3.3 & $24.5-25.5$ & 8.8 & 7.5 & 14.8 & 52.5 & 25.2 \\
\hline & 10 & $24.0-24.5$ & 8.6 & 7.4 & 22.9 & 42.0 & 27.7 \\
\hline 4-Me-2-O- & 1 & $22.5-23.0$ & 8.8 & 8.1 & 3.2 & 88.7 & 0.0 \\
\hline \multirow[t]{2}{*}{ pentanoic acid* } & 5 & 23.5 & 8.6 & 9.6 & 0.0 & 90.4 & 0.0 \\
\hline & 10 & 21.5 & 8.4 & 9.4 & 0.0 & 90.6 & 0.0 \\
\hline \multirow[t]{2}{*}{ isovaleric acid } & 2.5 & $23.5-24.5$ & 9.2 & 11.2 & 0.5 & 87.8 & 0.5 \\
\hline & 10 & $22.0-22.5$ & 9.0 & 11.5 & 0.0 & 88.5 & 0.0 \\
\hline
\end{tabular}

${ }^{a}$ Persentage values are calculated by the peak area of HPLC analysis. * precursors were added 8 hrs after inoculation

Next, we examined effect of the addition of an unusual amino acid, L-homoleucine, which was expected to increase TPPB and TPPD production. However, as shown in Table 4, Lhomoleucine had no effect on the production of TPPs. It may be explained that L-homoleuine is not recognized as a substrate for fatty acid biosynthesis by the producing organism because Lhomoleucine is not a natural amino acid. L-Homoleucine at $1 \mathrm{mg} / \mathrm{ml}$ decreased $\mathrm{pH}$ of culture broth and TPP production. 
Table 4. Effect of homoleucine on TPPs production

\begin{tabular}{|c|c|c|c|c|c|c|c|}
\hline \multirow[t]{2}{*}{ Amino acid } & \multirow{2}{*}{$\begin{array}{c}\text { Dose } \\
(\mathrm{mg} / \mathrm{ml})\end{array}$} & \multirow{2}{*}{$\begin{array}{c}\text { Inhibition } \\
\text { diameter } \\
\text { against } S \text {. } \\
\text { aureus Smith } \\
\quad(\mathrm{mm})\end{array}$} & \multirow[t]{2}{*}{$\mathrm{pH}$} & \multicolumn{4}{|c|}{ Ratio of TPPs $(\%)^{\mathrm{a}}$} \\
\hline & & & & A & B & $\mathrm{C}$ & $\mathrm{D}$ \\
\hline control & 0 & $23.5-24.5$ & $9.0-9.2$ & 7.8 & 11.5 & 65.9 & 14.8 \\
\hline \multirow[t]{3}{*}{ L-leucine } & 0.31 & $24.0-24.5$ & 8.8 & 7.4 & 7.6 & 80.2 & 4.8 \\
\hline & 0.63 & $23.5-24.0$ & 8.8 & 7.8 & 2.1 & 87.3 & 2.8 \\
\hline & 1.25 & $23.5-24.5$ & $8.6-8.8$ & 9.7 & 0.3 & 89.7 & 0.3 \\
\hline \multirow[t]{4}{*}{ L-homoleucine } & 0.04 & $23.5-24.0$ & 9.0 & 8.5 & 11.9 & 65.5 & 14.1 \\
\hline & 0.11 & 23.5 & 9.0 & 7.5 & 11.5 & 65.8 & 15.2 \\
\hline & 0.33 & 23.5 & 9.0 & 9.7 & 9.5 & 55.1 & 14.7 \\
\hline & 1 & $21.5-22.5$ & $8.8-9.0$ & 10.4 & 9.1 & 63.4 & 17.1 \\
\hline
\end{tabular}

${ }^{a}$ Percentage values are calculated by the peak area of HPLC analysis.

Improvement in TPPD productivity was further examined by the addition of its constituting fatty acid, 3-hydroxy-14-methylpentadecanoic acid (5), and was proved successful by its increased production in a dose-dependent manner up to $0.3 \mathrm{mg} / \mathrm{ml}$. However, this fatty acid when used at the higher doses caused growth inhibition and lowering of TPP production. The maximum production of TPPD was achieved to 2.2 fold by the addition of the fatty acid at 0.15 $0.3 \mathrm{mg} / \mathrm{ml}$ (Figure 4).

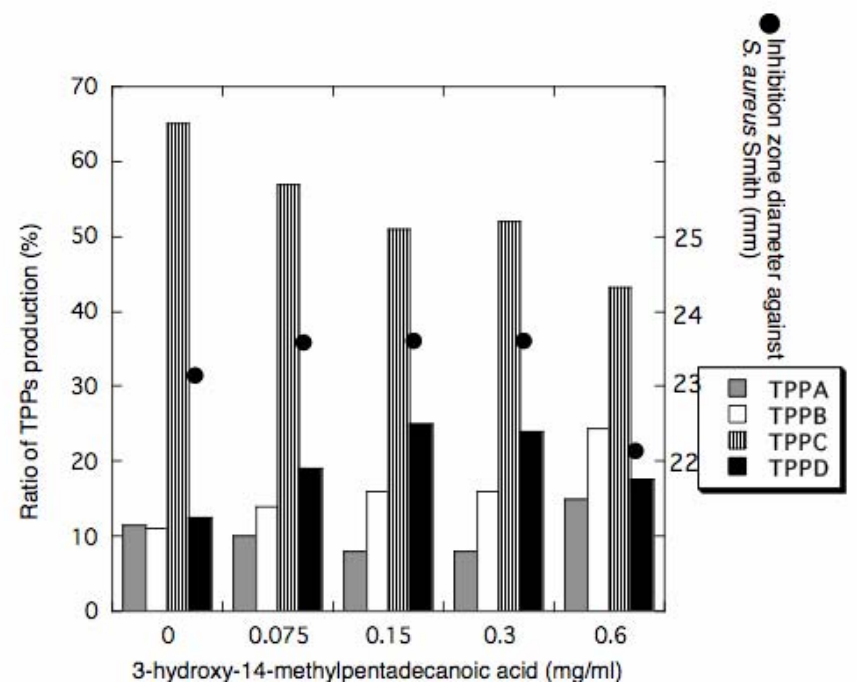

Figure 4. Effect of 3-hydroxy-14-methylpentadecanoic acid on TPPs production. TPPs producing organism were cultured adding with the indicated concentrations of racemic 3hydroxy-14-methylpentadecanoic acids for $48 \mathrm{~h}$. After cultivation, production ratio of TPPA 
(dotted column), TPPB (open column), TPPC (striped column) and TPPD (blacked column) are calculated by the peak area of HPLC analysis (for chromatographic protocol see experimental section). Values are means of triplicate determinations. Total TPPs productivities of the cultured broths were represented by the inhibition zone diameter against $S$. aureus Smith (solid circle).

Next, we examined the effect of the stereoisomers of 3-hydroxy-14methylpentadecanoicacids, 3(R)-isomer 9 and 3(S)-isomer 11, on TPPD production and found that 3(R)-isomer 9 was preferentially incorporated into TPPD to yield $28 \mu \mathrm{g} / \mathrm{ml}$, but on the contrary, the addition of 3(S)-isomer 11 has only slight effect on TPPD formation as shown in figure 5. These results suggest that 3(S)-isomer 11 can be incorporated into TPPs only after enzymatic isomerization, which are easily understandable because natural TPPD has 3(R)hydroxy-14-methylpentadecanoic acid. ${ }^{3}$

The fatty acids were synthesized as outlined in Schemes 1 and 2.

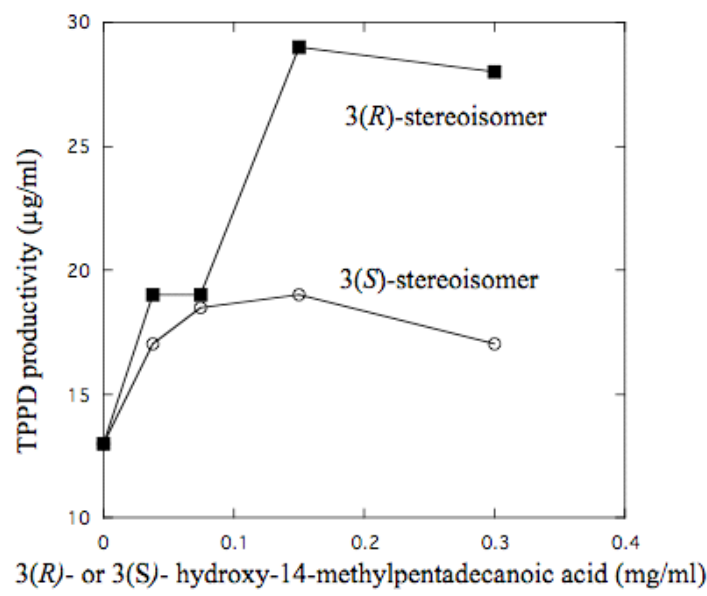

Figure 5. Effect of addition of 3(R)-or 3(S)-hydroxy-14-methylpentadecanoic acid on TPPD productivity. TPPs producing organism were cultured adding with the indicated concentrations of 3(R)- (solid square) and 3(S)-hydroxy-14-methylpentadecanoic acid (open circle) for $48 \mathrm{~h}$. After cultivation, productivities of TPPD are calculated by the peak area of HPLC analysis (for chromatographic protocol see experimental section). Values are means of triplicate determinations.

\section{Conclusions}

In summary, the present study showed the control of TPPs productions by supplementation of the biosynthetic precursors. TPPC were predominantly produced by the addition of L- and Dleucine, 4-methyl-2-oxo-pentanoic acid or isovaleric acid. The production of TPPD was affected, not by addition of L- and D-valine or L-homoleucine, but by addition of 3-methyl-2-oxo- 
butanoic acid or 3-hydroxy-14-methylpentadecanoic acids. These results indicate that iso type, even-carbon chain fatty acids can be produced via an alternative metabolic pathway of certain amino acids other than valine. Improved productivities of TPPs by the biosynthetic precursors shown in the present study could lead to usefulness for the industrial application.
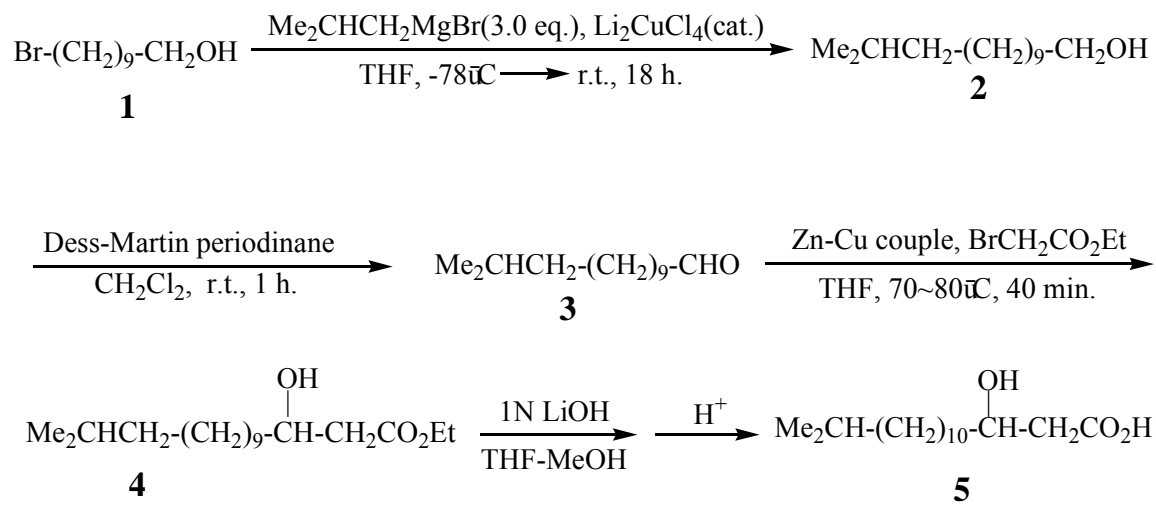

Scheme 1. Synthesis of racemic fatty acid (5).
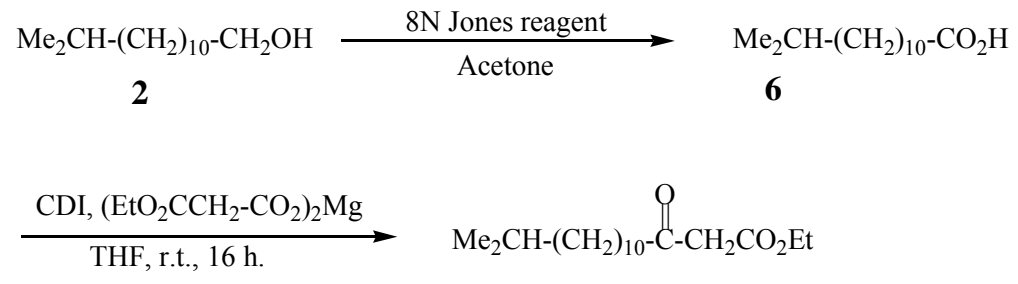

7

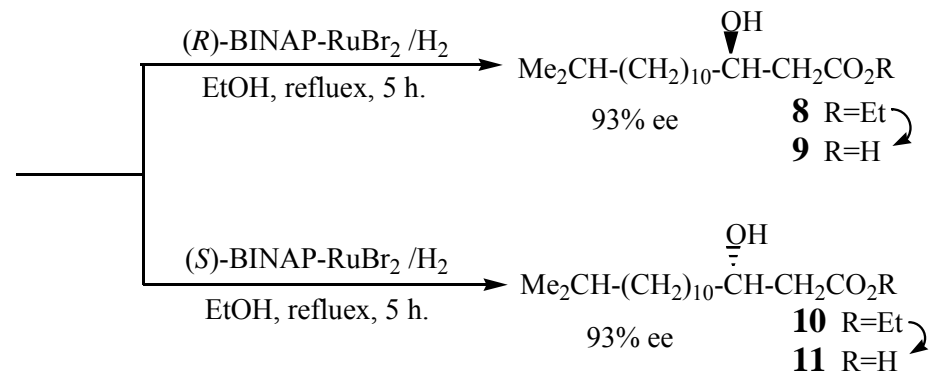

CDI: $N, N$-Carbonyldiimidazole

BINAP: 2,2'-Bis(diphenylphosphino)-1,1'-binaphthyl

Scheme 2. Asymmetric synthesis of 3(R)- and (S)-fatty acid (9 and 11). 


\section{Experimental Section}

\section{Cultivation}

Cultivation was carried out as reported previously ${ }^{1}$ expect for the addition of precursors. LLeucine, D-leucine, L-valine, D-valine or L-homoleucine was added to a $500 \mathrm{ml}$ Erlenmeyer flask containing $100 \mathrm{ml}$ culture medium before sterilization by autoclave. Isovaleric acid, 3methyl-2-oxo-butanoic acid sodium salt, 4-methyl-2-oxo-pentanoic acid sodium salt or synthetic 3-hydroxy-14-methylpentadecanoic acid was dissolved in DMSO, and the solution was added to a $500 \mathrm{ml}$ Erlenmeyer flask containing $100 \mathrm{ml}$ culture medium at a scheduled time after inoculation. Cultivation was carried out for $48 \mathrm{~h}$ at $27^{\circ} \mathrm{C}$. At $48 \mathrm{~h}$ after cultivation, $\mathrm{pH}$ of the cultured broths were measured by $\mathrm{pH}$ test papers and antimicrobial activity against $S$. aureus of those broths were assessed by conventional cylinder agar plate method.

\section{Materials}

3-Hydroxy-14-methylpentadecanoic acid (5). (Scheme 1). To a solution of 10-Bromo-1decanol 1 (5 g, $21 \mathrm{mmol})$ in anhydrous tetrahydrofuran $(50 \mathrm{ml})$ was added an excess of $2.0 \mathrm{M}$ isobutylmagnesium bromide $(40 \mathrm{ml}, 80 \mathrm{mmol})$ in diethylether in the presence of a catalytic amount of $0.1 \mathrm{~N}$ dilithium tetrachlorocuprate $(3 \mathrm{ml}, 0.3 \mathrm{mmol})$ in tetrahydrofuran at $-78^{\circ} \mathrm{C}$. The resulting mixture was stirred for $12 \mathrm{~h}$ at room temperature. After neutralization with saturated aqueous ammonium chloride solution, it was extracted with ethyl acetate. The solvent was washed with water, saturated sodium hydrogen carbonate aqueous solution and brine, dried over sodium sulfate and evaporated. The desired alcohol $2(4.5 \mathrm{~g})$ as a pale yellowish oil. ${ }^{1} \mathrm{H}-\mathrm{NMR}$ $\mathrm{CDCl}_{3} \delta 0.86(6 \mathrm{H}, \mathrm{d}, \mathrm{J}=6.6 \mathrm{~Hz}, 2 \mathrm{xMe}), 3.64\left(2 \mathrm{H}, \mathrm{q} . \mathrm{J}=6.4 \mathrm{~Hz}, 1-\mathrm{H}_{2}\right)$.

To a suspension of the Dess-Martin triacetoxyperiodinane (3.562 g, $8.4 \mathrm{mmol})$ in dichloromethane $(20 \mathrm{ml})$ was added a solution of $2(1.284 \mathrm{~g}, 6 \mathrm{mmol})$ in dichloromethane $(5 \mathrm{ml})$ at room temperature. The resulting mixture was stirred for $1 \mathrm{~h}$. After evaporation, the residue was dissolved in diethylether. Removal of the precipitation, the filtrate was washed with saturated sodium hydrogen carbonate aqueous solution, saturated sodium thiosulfate aqueous solution and brine, dried over sodium sulfate and evaporated to give the corresponding aldehyde $3(1.125 \mathrm{~g})$ as a pale yellowish oil. ${ }^{1} \mathrm{H}-\mathrm{NMR}\left(\mathrm{CDCl}_{3}\right) \delta 0.86(6 \mathrm{H}, \mathrm{d}, \mathrm{J}=6.6 \mathrm{~Hz}, 2 \mathrm{xMe}), 2.42(2 \mathrm{H}$, $\mathrm{dt}, \mathrm{J}=7.4$ and $\left.1.6 \mathrm{~Hz}, 2-\mathrm{H}_{2}\right), 9.77(1 \mathrm{H}, \mathrm{t}, \mathrm{J}=1.8 \mathrm{~Hz}, \mathrm{CHO})$.

To a suspension of $\mathrm{Zn}-\mathrm{Cu}$ couple $(1.2 \mathrm{~g})$ in anhydrous tetrahydrofuran $(30 \mathrm{ml})$, was added $3 \mathrm{ml}$ of a solution of ethyl bromoacetate $(1.77 \mathrm{~g}, 10.6 \mathrm{mmol})$ and $3(1.125 \mathrm{~g}, 5.3 \mathrm{mmol})$ in anhydrous tetrahydrofuran $(15 \mathrm{ml}){ }^{8}$ The mixture was warmed gently till the reaction started. The remaining solution was added dropwise, refluxed for $30 \mathrm{~min}$. The mixture was treated with saturated ammonium chloride aqueous solution under cooling and filtered. The organic layer was separated and the aqueous layer was extracted with ethyl acetate. The combined organic extracts were washed with brine and dried over sodium sulfate. The solvent was evaporated to give a syrup which was subjected to chromatography on silica gel. Elution with toluene-ethyl acetate $(0-3 \%)$ gave the 3-hydroxy ester $4(920 \mathrm{mg}, 57.8 \%) .{ }^{1} \mathrm{H}-\mathrm{NMR}\left(\mathrm{CDCl}_{3}\right) \delta 0.86(6 \mathrm{H}, \mathrm{d}, \mathrm{J}=6.6 \mathrm{~Hz}$, 
2xMe), $2.39\left(1 \mathrm{H}, \mathrm{dd}, \mathrm{J}=16.4\right.$ and $\left.9.1 \mathrm{~Hz}, 2-\mathrm{H}_{\mathrm{a}}\right), 2.50\left(1 \mathrm{H}, \mathrm{dd}, \mathrm{J}=16.4\right.$ and $\left.3.0 \mathrm{~Hz}, 2-\mathrm{H}_{\mathrm{b}}\right), 2.92$ $(1 \mathrm{H}, \mathrm{d}, \mathrm{J}=4.0 \mathrm{~Hz}, \mathrm{OH}), 3.99(1 \mathrm{H}, \mathrm{m}, 3-\mathrm{H}), 4.17\left(2 \mathrm{H}, \mathrm{q}, \mathrm{J}=7.1 \mathrm{~Hz}, \mathrm{OCH}_{2} \mathrm{Me}\right) ; \mathrm{HRESI}-\mathrm{MS} \mathrm{m} / \mathrm{z}$ $323.25543(\mathrm{M}+\mathrm{Na})^{+}$(calcd. 323.25621 for $\mathrm{C}_{18} \mathrm{H}_{36} \mathrm{NaO}_{3}$ ).

Compound 4 (750 mg, $2.5 \mathrm{mmol})$ was dissolved in tetrahydrofuran (5 ml) and methanol (2.5 $\mathrm{ml})$. $1 \mathrm{~N}$ lithium hydroxide aqueous solution $(3 \mathrm{ml}, 3 \mathrm{mmol}$ ) was added and stirred overnight at room temperature. The reaction mixture was concentrated. The residue was poured into ethyl acetate, acidified with $1 \mathrm{~N}$ hydrochloric acid to $\mathrm{pH} 3$, and extracted with ethyl acetate. The extract was washed with water and brine, dried over sodium sulfate. The solvent was evaporated to give the racemic acid $5(635 \mathrm{mg}, 93.4 \%)$ as colorless plates. ${ }^{1} \mathrm{H}-\mathrm{NMR}\left(\mathrm{CDCl}_{3}\right) \delta 0.86(6 \mathrm{H}, \mathrm{d}, \mathrm{J}=6.6 \mathrm{~Hz}$, 2xMe), 1.06-1.60 (23 H, m), $2.47\left(1 \mathrm{H}, \mathrm{dd}, J=16.6\right.$ and $\left.9.0 \mathrm{~Hz}, 2-\mathrm{H}_{\mathrm{a}}\right), 2.58(1 \mathrm{H}, \mathrm{dd}, J=16.6$ and $3.2 \mathrm{~Hz}, 2-\mathrm{H}_{\mathrm{b}}$ ) and $4.02(1 \mathrm{H}, \mathrm{m}, 3-\mathrm{H})$; HRESI-MS m/z $271.22547(\mathrm{M}-\mathrm{H})^{-}$(calcd. 271.22732 for $\left.\mathrm{C}_{16} \mathrm{H}_{31} \mathrm{O}_{3}\right)$.

3(R)-and (S)-Hydroxy-14-methylpentadecanoic acids (9 and 11) (Scheme 2). To a solution of $2(856 \mathrm{mg}, 4 \mathrm{mmol})$ in acetone $(8 \mathrm{ml})$ was added $8 \mathrm{M}$ Jones reagent $(2.8 \mathrm{ml})$ dropwise under icecooling and stirred for $1 \mathrm{~h}$. After addition of an excess of isopropanol, the reaction mixture was concentrated. The residue was dissolved in ethyl acetate, washed with water and brine, dried over sodium sulfate. The solvent was evaporated, the residue was subjected to chromatography on silica gel. Elution with toluene-ethyl acetate (0-10\%) gave the carboxylic acid 6 (748 $\mathrm{mg}$, $81.3 \%)$ as colorless powder. ${ }^{1} \mathrm{H}-\mathrm{NMR}\left(\mathrm{CDCl}_{3}\right) \delta 0.86(6 \mathrm{H}, \mathrm{d}, \mathrm{J}=6.6 \mathrm{~Hz}, 2 \mathrm{xMe}), 2.36(2 \mathrm{H}, \mathrm{t}$, $\left.\mathrm{J}=7.6 \mathrm{~Hz}, 2-\mathrm{H}_{2}\right), 11.0(1 \mathrm{H}, \mathrm{br}, \mathrm{COOH})$; HRESI-MS m/z 227.19991 (M-H) ${ }^{-}$(calcd. 227.20110 for $\mathrm{C}_{14} \mathrm{H}_{27} \mathrm{O}_{2}$ )..

$N, N^{\prime}$-carbonyldiimidazole (272 $\left.\mathrm{mg}, 2.3 \mathrm{mmol}\right)$ was added to a solution of 6 (437 $\left.\mathrm{mg}, 1.9 \mathrm{mml}\right)$ in anhydrous tetrahydrofuran $(10 \mathrm{ml})$ and then refluexed for $6 \mathrm{~h}$. A suspension of $\left(\mathrm{EtO}_{2} \mathrm{C}\right.$ $\left.\mathrm{CH}_{2} \mathrm{CO}_{2}\right)_{2} \mathrm{Mg}(555 \mathrm{mg}, 2.5 \mathrm{mmol})$ in tetrahydrofuran $(20 \mathrm{ml})$ was added at room temperature, stirred at the same temperature for $16 \mathrm{~h} .{ }^{9}$ After filtration and evaporation, the residue was partitioned between ethyl acetate $(20 \mathrm{ml})$ and $0.5 \mathrm{~N}$ hydrochloric acid $(20 \mathrm{ml})$. The aqueous layer was extracted with ethyl acetate, the combined ethyl acetate extracts were washed with saturated sodium hydrogen carbonate aqueous solution and brine, dried over sodium sulfate. The solvent was evaporated, the residue was subjected to chromatography on silica gel. Elution with toluene gave the $\beta$-keto ester 7 (476 mg, 84.2\%). ${ }^{1} \mathrm{H}-\mathrm{NMR}\left(\mathrm{CDCl}_{3}\right) \delta 0.86(6 \mathrm{H}, \mathrm{d}, \mathrm{J}=6.6 \mathrm{~Hz}, 2 \mathrm{xMe}), 2.53$ $\left.\left(2 \mathrm{H}, \mathrm{d}, \mathrm{J}=7.4 \mathrm{~Hz}, 4-\mathrm{H}_{2}\right), 3.42\left(2 \mathrm{H}, \mathrm{s}, 2-\mathrm{H}_{2}\right), 4.20\left(2 \mathrm{H}, \mathrm{q}, \mathrm{J}=7.1 \mathrm{~Hz}, \mathrm{COOCH}_{2} \mathrm{Me}\right)\right)$; HRESI-MS $\mathrm{m} / \mathrm{z} 321.23980(\mathrm{M}+\mathrm{Na})^{+}$(calcd. 321.24056 for $\mathrm{C}_{18} \mathrm{H}_{34} \mathrm{NaO}_{3}$ ).

Compound 7 (149 mg, $0.5 \mathrm{mmol}$ ) was dissolved in degassed anhydrous ethanol $(2 \mathrm{ml})$, then added to in situ generated (R)-BINAP- $\operatorname{RuBr}_{2}$ (3 mol\%) under argon current. ${ }^{10}$ The argon atomosphere was replaced with hydrogen and the mixture was refluxed for $5 \mathrm{~h}$. After evaporation, the residue was subjected to chromatography on silica gel. Elution with tolueneethyl acetate (0-3\%) gave the $R$ hydroxy ester $8(149 \mathrm{mg})$ as colorless powder; HRESI-MS $\mathrm{m} / \mathrm{z}$ $323.25577(\mathrm{M}+\mathrm{Na})^{+}$(calcd. 323.25621 for $\left.\mathrm{C}_{18} \mathrm{H}_{36} \mathrm{NaO}_{3}\right)$. Alkaline hydrolysis of 8 gave the desired acid 9. In a similar manner, using $(S)$-catalyst, the $S$ hydroxy acid $\mathbf{1 1}$ was obtained. The stereochemistry at C-3 of $\mathbf{9}$ and $\mathbf{1 1}$ was inferred to be $R$ and $S$ on the basis of the value of the 
optical rotation. ${ }^{11}$ NMR spectra and TLC of $\mathbf{9}$ and 11 were identical with those of 5. 10: HRESIMS m/z 323.25499 $(\mathrm{M}+\mathrm{Na})^{+}$(calcd. 323.25621 for $\mathrm{C}_{18} \mathrm{H}_{36} \mathrm{NaO}_{3}$ ).

9: $[\alpha]^{27}{ }_{\mathrm{D}}-13.8^{\circ}\left(\mathrm{c} 1.0, \mathrm{CHCl}_{3}\right)$; HRESI-MS $\mathrm{m} / \mathrm{z} 271.23024(\mathrm{M}-\mathrm{H})^{-}$(calcd. 271.22732 for $\left.\mathrm{C}_{16} \mathrm{H}_{31} \mathrm{O}_{3}\right)$. 11: $[\alpha]^{27}{ }_{\mathrm{D}}+13.8^{\circ}\left(c 1.0, \mathrm{CHCl}_{3}\right)$; HRESI-MS m/z 271.22921 (M-H) ${ }^{-}$(calcd. 271.22732 for $\mathrm{C}_{16} \mathrm{H}_{31} \mathrm{O}_{3}$ ).

The enantiomeric excess of its methyl ester was determined by ${ }^{1} \mathrm{H}-\mathrm{NMR}$ in the presence of $(+) \operatorname{Eu}(\mathrm{tfc})_{3}$.

\section{Antimicrobial Activity}

Antimicrobial activities against S. aureus Smith of the cultured broths were assayed by conventional cylinder agar plate method. $300 \mu \mathrm{l}$ of each cultured broth was poured into a cylinder stands on the surface of the Mueller-Hinton agar (DIFCO) containing S. aureus Smith $\left(10^{7} \mathrm{CFU} / \mathrm{ml}\right)$. CFU stands for colony forming units. Plates were incubated at $37^{\circ} \mathrm{C}$ for $18 \mathrm{~h}$, then measured growth inhibitory zone diameter. These inhibition zone diameters of $S$. aureus Smith represent the total TPP productivity of the cultured broths.

\section{Analytical Methods}

Five milliliters of fermentation broth were added to an equal volume of acetone, and the resulting suspension was centrifuged. The supernatant was subjected to a column of $1 \mathrm{ml}$ wet volume of Diaion HP20 (Mitsubishi Chemical Co.) after dilution with an equal volume of de-ionized water. The column was washed with $50 \%$ aqueous methanol and then eluted with acetone. The evaporated eluate was dissolved in $1 \mathrm{ml}$ methanol. The solution was then subjected to HPLC (RSpak, DS-413, Shodex $5 \mu \mathrm{m}, 150$ x $4.6 \mathrm{~mm}$ inner diameter), using acetonitrile/0.01 M trifluoroacetic acid aqueous solution as the mobile phase by the gradient elution mode (acetonitrile, $10-70 \%, 20 \mathrm{~min}$ ). The mobile phase flowed at rate of $0.8 \mathrm{ml} / \mathrm{min}$, and was monitored at wavelength of $205 \mathrm{~nm}$. The production of TPP was calculated from each peak area. Values are the means of triplicate determinations.

\section{Acknowledgements}

We express our special thanks to Dr. R. Sawa and Mrs. Y. Kubota, Microbial Chemistry Research Center, for measurement of NMR and MS spectra.

\section{References}

1. Hashizume, H.; Igarashi, M.; Hattori, S.; Hori, M.; Hamada, M.; Takeuchi, T. J. Antibiotics 2001, 54, 1054

2. Hashizume, H.; Hattori, S.; Igarashi, M.; Akamatsu, Y. J. Antibiotics 2004, 57, 394

3. Hashizume, H.; Hirosawa, S.; Sawa, R.; Muraoka, Y.; Ikeda, D.; Naganawa, H.; Igarashi, M. J. Antibiotics 2004, 57, 52 
4. Massey, L. K.; Sokatch, J. R.; Conrad, R. S. Bacteriol. Rev. 1976, 40, 42-54.

5. Boeck, L. D.; Wetzel, R. W. J. Antibiotics 1990, 43: 607

6. Beck, H. C.; Hansen, A. M.; Lauritsen, F. R. FEMS Microbiol. Lett. 2003, 220, 67

7. Fabrizio, B., Joveetic, S.; Feroggio, M.; L. Gastaldo, Selva, E.; Marinelli, F. J. Antibiotics 2004, 57, 37

8. Kalyanakumar, R.; Chadha, M.S.; Chattopadhyay, A.; Mamdapur, V.R. Indian J. Chem. 1996, 35B, 356

9. Brooks, D.W.; Lu, L.D.L.; Masamune, S. Angew. Chem. Int. Ed. Engl. 1979, 18, 72

10. Ratovelomanana-Vidal, V.; Girard, C.; Touati, R.; Tranchier, J.P.; Ben Hassine, S.; Genet, J.P. Adv. Synth. Catal. 2003, 345, 261

11. Ubukata, M.; Kinuma, K.; Isono, K.; Nelson, C.C.; Gregson, J.M.; Mccloskey, J.A. J. Org. Chem. 1992, 57, 6392 